\title{
How much does it cost to go off-grid with renewables? \\ A case study of a polygeneration system for a neighbourhood in Hermosillo, Mexico
}

\author{
Moritz Wegener ${ }^{1,2, *[0000-0003-3070-794 X]}$, Carlos Lopez Ordóñez ${ }^{1[0000-0002-4199-9813]}$, Antonio Isal- \\ gué $^{[0000-0002-4354-5831]}$, Anders Malmquist ${ }^{2[0000-0002-4479-344 X]}$, Andrew Martin ${ }^{2[0000-0002-3661-7016]}$ \\ ${ }^{1}$ Architecture \& Energy-School of Architecture, Polytechnic University of Catalonia (UPC), \\ Barcelona, Spain, \\ ${ }^{2}$ Heat and Power Technology, Department of Energy Technology, KTH Royal Institute of Tech- \\ nology, Stockholm, Sweden \\ *Corresponding author: mbgw@kth.se, Tel.: +46 87906000
}

\begin{abstract}
As governments and companies struggle to meet their own objectives for the energy transition, more innovative social and technological measures are needed to reduce Greenhouse Gas (GHG) emissions. For this purpose an assessment of an off-grid polygeneration system, which can serve the electric and cooling demand of a neighbourhood in Hermosillo, Mexico, has been conducted. Energy computations have been done, the energy demand of one dwelling has been measured to ascertain the correctness of the computations, and a demand model for the entire neighbourhood has been created. Based on the model, an off-grid polygeneration system has been designed, which uses a biodiesel engine, PV panels, and an absorption chiller. The system has been optimized for its economic performance and is compared to the currently used system. The results show that the polygeneration system with higher energy efficiency could reduce GHG emissions down to $14 \%$. However, electricity in Hermosillo is heavily subsidised making it harder for innovative systems to compete. Moreover, even without the state subsidies to the end-user, the polygeneration system has still a nearly 30\% higher Net Present Cost (NPC) than the conventional system over its project lifetime of 20 years. Nonetheless, with precise political incentives and further advances in the applied technologies, small-scale renewable polygeneration systems could become cost-efficient alternatives in the near future.
\end{abstract}

Keywords: Urban energy systems, bio-solar, off-grid polygeneration

\section{Introduction}

With the amount of Greenhouse Gases (GHG) in the world's atmosphere still rising innovative and cost-effective measures to promote renewable energies are needed [1]. Motivated social communities initiating small-scale, local energy projects have been identified as crucial for developing technologies and processes for the renewable energy transition [2]. In this context, decentralized polygeneration systems, which serve several energy demands at once (e.g. electricity, heat and cooling), could be a more cost-effective alternative to the conventional energy provision based on fossil fuels. Combining this technology with renewable resources like biomass or solar can provide sustainable and autonomous energy systems with benefits but also challenges [3-5].

An example of a biomass-fired polygeneration system using absorption chilling (ACh) technology to serve a building complex has been given by Caliano et al. [6]. 
They conclude that these systems are highly effected by the electricity prices and the incentives set for cooling applications. Another bio-solar polygeneration system providing electricity, heat and cooling for a local community has been proposed by Chua et al. [7]. They found that with low renewable energy penetration, the system outperforms the reference model economically and ecologically.

While there have been studies using EnergyPlus and HOMER for electricity production in building clusters [8], no such study could be found where both engine tools have been used supplementing each other. Therefore, we present an innovative approach by combining the simulation tools EnergyPlus, which is employed for a thorough demand analysis, and HOMER, which is subsequently used for an economic optimization of an off-grid polygeneration system designed according to the demand analysis. The case study is performed for a block of 16 closely situated houses in the city of Hermosillo, Mexico, with high thermal and electrical demand fluctuations. Finally, the results of this polygeneration system are compared to the reference system, which conventionally relies on a connection to the electric grid and transformation of electricity for thermal services. The findings are put into the political and technological context of the energy transition and local initiatives further adding to the novelty of the paper.

\section{Methodology}

The methodologic approach is visualized in Fig. 1. In a first step, energy consumption, energy demand and architectural data of one of the houses facing south has been measured and collected. Using DesignBuilder and EnergyPlus [9] a simulation model was constructed, which accurately represents the electric and thermal demand of the house on an hourly basis. Using this model, the energy demand for all 16 houses with their different exposure to the sun have been calculated and summed up.

In a second step a renewable polygeneration system based on a biodiesel generator and PV panels has been designed, which satisfies the different energy demands without connection to the electric grid. Then the demand data together with technical as well as economic data from commercial, governmental and academic sources has been entered into the HOMER Energy software [10]. In HOMER, the system component sizes have been optimized for minimum Net Present Cost (NPC) under the restriction of having to satisfy the minimum capacity shortage and operation reserve. The NPC takes into account the current value of all foreseen present and future expenses for components and for the entire system over the project lifetime. To test the influence of different variables on the results, a sensitivity analysis has been conducted. The reference case has also been modelled to allow for comparison of the two systems.

Finally, the results are studied in respect to their environmental, economic, and energetic repercussions for the dwellings inhabitants. The significance of the polygeneration system has been put into the context of the. 


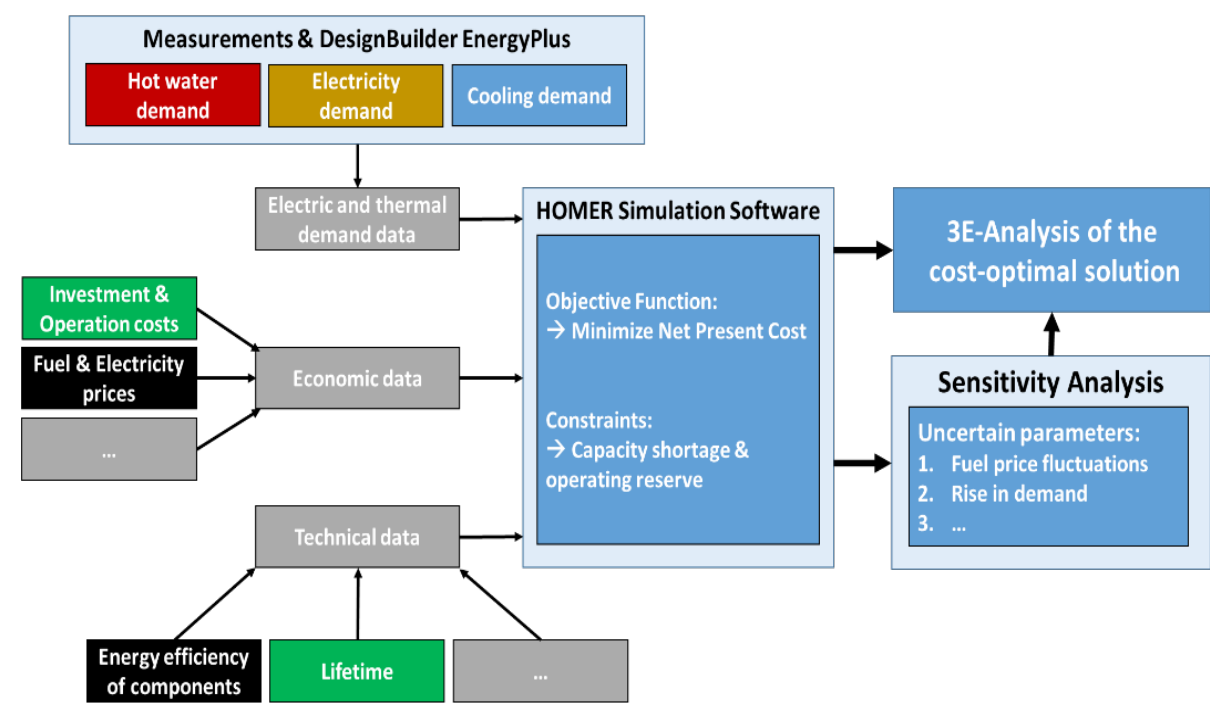

Fig. 1. Methodology for optimal system and component sizing

\section{$3 \quad$ Site and System Description}

\subsection{Hermosillo: Electric and Thermal Demand of Dwellings}

Hermosillo features a hot desert climate with an average yearly temperature of $25^{\circ} \mathrm{C}$ and a yearly oscillation of nearly $15^{\circ} \mathrm{C}$ with temperatures reaching up to $45^{\circ} \mathrm{C}$ in summer. The annual precipitation is $387 \mathrm{~mm}$ and the relative yearly humidity is $43 \%$. The average daily solar radiation during all of the year is $5.71 \mathrm{kWh} /(\mathrm{m} 2 \cdot$ day). Due to its traditional building style, Hermosillo consists of many scattered single-family dwellings with high exposure to solar radiation. These conditions lead to a high cooling demand for air conditioning during the summer months.

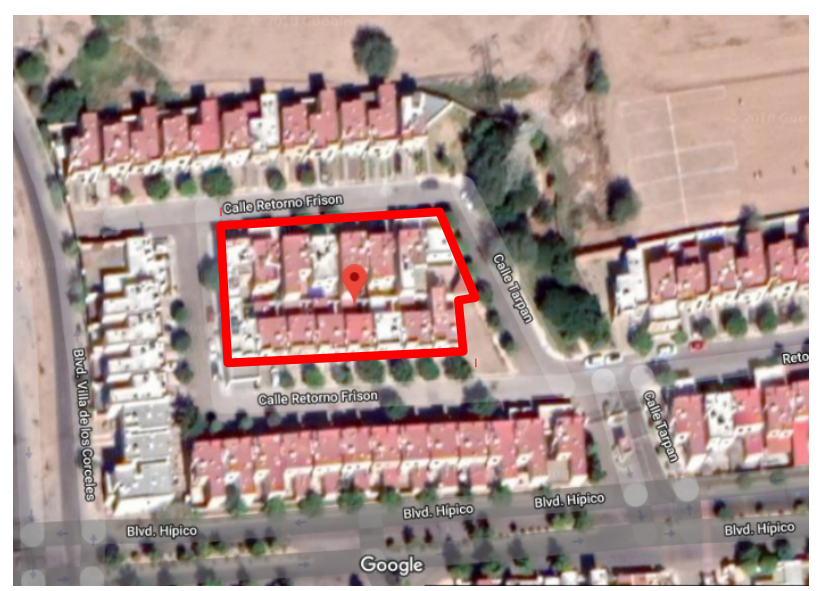

Fig. 1. Studied dwelling block in Hermosillo, Mexico 
The scope of this study is a block consisting of 16 dwellings, which are located at $29^{\circ} 04^{\prime} 40.1^{\prime \prime N} 111^{\circ} 01^{\prime} 30.4^{\prime \prime} \mathrm{W}$ and are shown in Fig. 1. The roof area of the example dwelling is $48.8 \mathrm{~m}^{2}$, which will be considered the average roof area of all dwellings.

As can be seen in Fig. 1 the measured total electricity consumption rises significantly from May to October reaching its peak value in June. Subtracting the base electricity demand of $215 \mathrm{kWh} /$ month, the so deduced AC electric demand resembles the calculated AC electric demand of the Energy Plus simulation. In the simulation, a Coefficient of Performance (COP) of the electric chillers (EChs) of 1.83 is assumed. Any differences can be mostly attributed to unexpected vacations or increased occupation of the dwelling. It should be noted that the Mexican government heavily subsidizes electricity costs during the hot season (May-October), which amplifies the rapid demand changes.

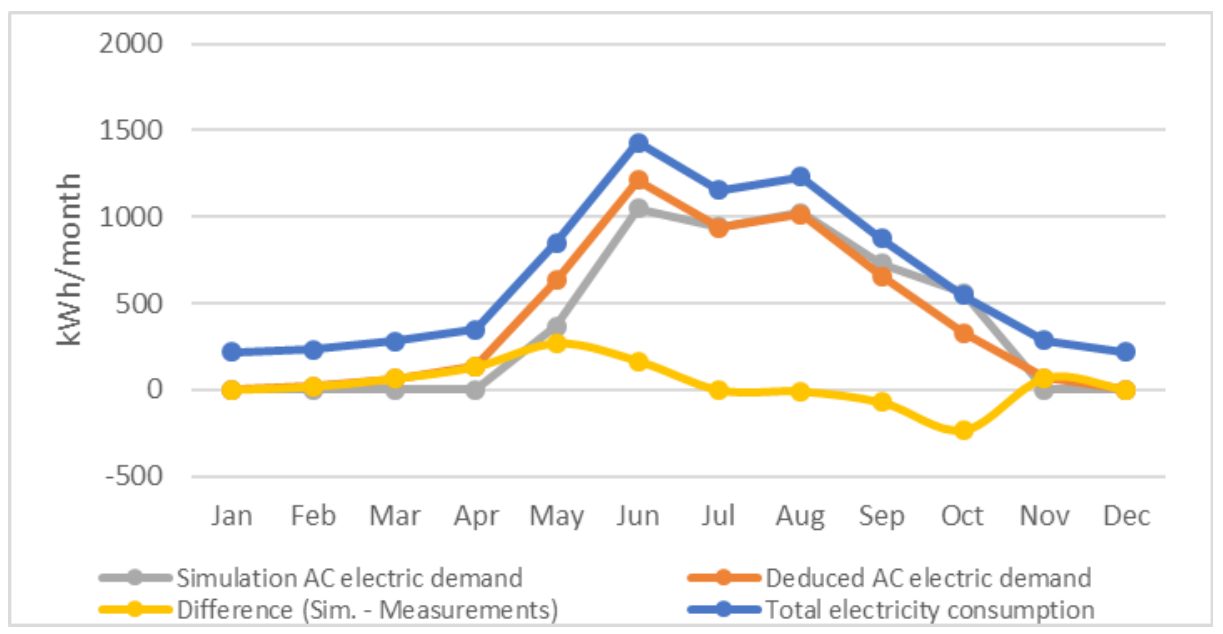

Fig. 1. Electricity demand for electricity and air conditioning of one dwelling facing south

The reliability of the simulation can be estimated by calculating the Normalized Mean Bias Error (NMBE) and the Coefficient of Variation of the Root Mean Square Error (CVRMSE), as proposed by the ASHRAE Guideline 2002-14 [11]. The formulae for the NMBE and the CVRMSE for simulation and measured data are [12]:

$E$

$$
\begin{aligned}
& \frac{\sum_{i=1}^{n=12}\left(i \dot{i} s i-E_{m i}\right)}{(n-p) \times \dot{E}_{m}} \\
& \mathrm{NMBE}=100 \times \dot{i}
\end{aligned}
$$




$$
\left(\frac{\sum_{i=1}^{n=12}\left(E_{s i}-E_{m i}\right)^{2}}{(n-p)}\right.
$$

CV RMSE $=100 \times i^{1 / 2} i / E_{m}$

where $E_{s i}$ is the calculated value of the simulation for month $\mathrm{i}, \quad E_{m i}$ is the measured value for month i, $\quad E_{m}$ is the average value of measured monthly consumption, $\mathrm{i}$ is the particular month, $\mathrm{n}$ is the total amount of months and $\mathrm{p}=1$. With $\mathrm{NMBE}=8.63 \%$ and $\mathrm{CVRMSE}=30.57 \%$ the simulation values can be considered as accurate enough.

Using the simulation software and the measurement data, the electricity and the AC demands for all the dwellings of the building block have been calculated with the following dwelling orientations:

- Row houses: 6 houses facing south and 6 houses facing north

- Corner houses: 1 house facing South-East, 1 house facing South-West, 1 house facing North-East, 1 house facing North-West

Fig. 1 shows the computed electricity demand for AC with the afore-mentioned COP of 1.83 and the remaining electricity demand for all 16 dwellings from a Thursday to a Sunday in June. For the remaining electricity demand, a typical residential behaviour has been assumed. It can be seen that the AC electricity demand rises abruptly at $07.00 \mathrm{~h}$ and stays high until $09.00 \mathrm{~h}$. The same behaviour is observed from $17.00 \mathrm{~h}$ until 24.00h during weekdays and from $08.00 \mathrm{~h}$ until $24.00 \mathrm{~h}$ during weekends, which is when the dwelling is generally populated by the inhabitants.

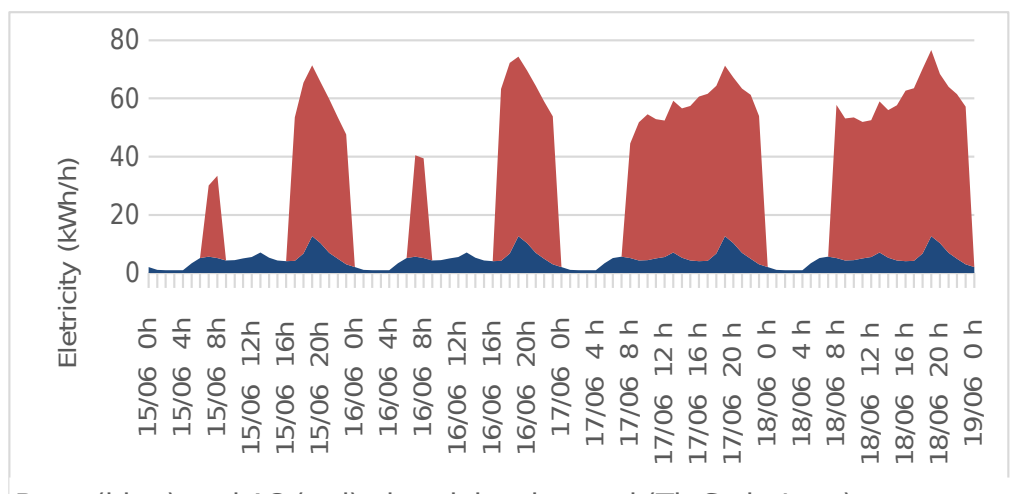

Base (blue) and AC (red) electricity demand (Th-Su in June)

Fig. 1. Computed total electricity and AC demand for all 16 dwellings in June 


\subsection{Polygeneration and Reference System}

In Fig. 1 the system layout of the proposed polygeneration system and the reference system are visualized. The proposed polygeneration system generates electricity using PV panels and a diesel engine fuelled with biodiesel. Batteries can store excess electricity and a converter is employed for electricity conversion. The demand for air conditioning can be met by a thermally driven absorption chiller (ACh) which during peak demand hours is supported by electricity-driven chillers (EChs). Apart from architectural design and measured data of the dwelling, scientific, governmental, and commercial sources have been used to quantify key parameters. A list of these key parameters for the simulation and their references is shown in Table 1.

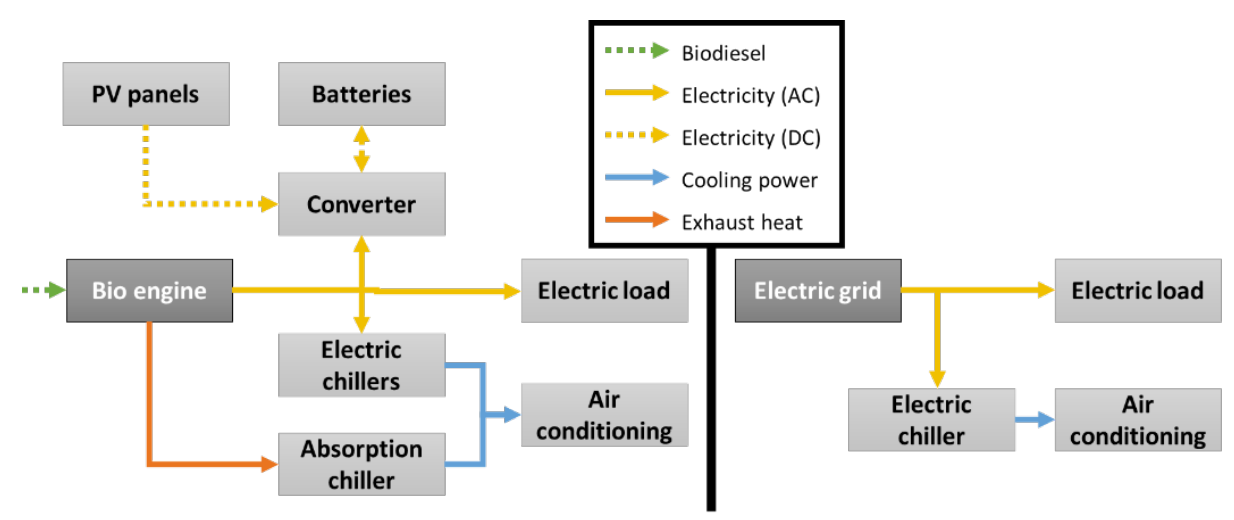

Fig. 1. Bio-solar polygeneration system (left) and reference system (right) 
Table 1. Key technical and economic simulation parameters

\begin{tabular}{|c|c|c|}
\hline Component & Characteristics & Value \\
\hline $\begin{array}{l}\text { Diesel Engine \& } \\
\text { Generator }\end{array}$ & $\begin{array}{l}\text { Capital costs: } \\
\text { O\&M costs } \\
\text { Mean electric efficiency: } \\
\text { Mean thermal effi- } \\
\text { ciency: } \\
\text { Lifetime } \\
\text { Fuel price (Biodiesel) }\end{array}$ & $\begin{array}{l}500 \mathrm{USD} / \mathrm{kW}_{\mathrm{e}}[13] \\
0.025 \mathrm{USD} /\left(\mathrm{op} . \mathrm{hr} \cdot \mathrm{kW}_{\mathrm{e}}\right)[13] \\
35 \% \\
45 \% \\
15,000 \text { hours } \\
0.8 \text { USD/L [14] }\end{array}$ \\
\hline $\begin{array}{l}\text { Electric Chillers } \\
\text { (EChs) }\end{array}$ & $\begin{array}{l}\text { COP: } \\
\text { Capital costs: }\end{array}$ & $\begin{array}{l}1.83 \\
\text { Already installed }\end{array}$ \\
\hline $\begin{array}{l}\text { ACh equipment } \\
\text { (incl. heat ex- } \\
\text { changer) }\end{array}$ & $\begin{array}{l}\text { COP: } \\
\text { Capital costs (system): } \\
\text { O\&M costs (system): }\end{array}$ & $\begin{array}{l}0.7 \\
100 \text { USD/kW [15] } \\
0.013 \text { USD/kWh [15] }\end{array}$ \\
\hline PV panels & $\begin{array}{l}\text { Capital costs: } \\
\text { O\&M costs: } \\
\text { Max. efficiency: } \\
\text { Area per peak power: }\end{array}$ & $\begin{array}{l}1,500 \mathrm{USD} / \mathrm{kW}_{\mathrm{p}}[16] \\
0.15 \mathrm{USD} /(\mathrm{kW} \cdot \mathrm{yr})[17] \\
15 \% \\
8 \mathrm{~m}^{2} / \mathrm{kW}_{\mathrm{p}}\end{array}$ \\
\hline Li-Ion Batteries & $\begin{array}{l}\text { Capital costs: } \\
\text { Minimum Stage of } \\
\text { Charge: }\end{array}$ & $\begin{array}{l}1,000 \text { USD/kWh [16] } \\
20 \%[16]\end{array}$ \\
\hline $\begin{array}{l}\text { Cooling system } \\
\text { (tubing, pumps, } \\
\text { control etc.) }\end{array}$ & $\begin{array}{l}\text { Capital costs: } \\
\text { O\&M costs: }\end{array}$ & $\begin{array}{l}70,000 \text { USD [18] } \\
1,000 \text { USD/yr }\end{array}$ \\
\hline Electric grid: & Grid power price: & 0.23 USD/kWh ${ }^{1}$ \\
\hline $\begin{array}{l}\text { System paramet- } \\
\text { ers }\end{array}$ & $\begin{array}{l}\text { Real discount rate: } \\
\text { Lifetime: } \\
\text { Max. capacity shortage }\end{array}$ & $\begin{array}{l}3.85 \% \\
20 \text { years } \\
0\end{array}$ \\
\hline
\end{tabular}

${ }^{1}$ The electric grid costs used are the production costs as stated on the electricity bill of the inhabitants. The inhabitants pay a lower price than the one stated here due to government subsidies after the production costs.

Whenever the ACh cannot satisfy the complete cooling demand during peak demand

$$
P
$$

times, the amount of electricity needed for the EChs ( $\quad$ i $e l, E C)$ has to be calcui

lated. Using energy balances for total electricity and total heat demand together with the energy efficiencies of the engine and the COPs of the different chillers, the following formula has been derived:

$$
P_{e l, E C}=\frac{Q_{t h, t}-P_{e l, R} \times C O P_{A C} \times \frac{\eta_{t h, e n g}}{\eta_{e l, e n g}}}{C O P_{E C}+C O P_{A C} \times \frac{\eta_{t h, e n g}}{\eta_{e l, e n g}}}
$$

where $P_{e l, R}$ and $P_{e l, E C} \quad$ are the remaining electric demand needed without AC and the electric demand needed for the electric chiller; $Q_{t h, t}$ is the total 
thermal demand; $\eta_{\text {th,eng }}$ and $\eta_{e l, \text { eng }}$ are the thermal and the electric efficiency of the engine; $C O P_{E C}$ and $C O P_{A C}$ are the COPs of the EChs and of the Ach, respectively.

\section{$4 \quad$ Results}

The component sizes and annual production of the cost-optimal polygeneration system are listed in Table 1. The minimum generator size has been determined to be 61 $\mathrm{kW}_{\mathrm{e}}$ to be able to satisfy the maximum thermal energy demanded by the ACh (54 $\mathrm{kW}_{\mathrm{th}}$ ) as well as the remaining electric demand. The engine would produce 80.7 $\mathrm{MWh}_{\mathrm{e}}$ or $72.7 \%$ of the total electricity produced per year as well as $111.6 \mathrm{MWh}_{\text {th }}$ of recoverable heat of which the ACh would use $76.4 \mathrm{MWh}_{\text {th }}$ to produce $53.5 \mathrm{MWh}_{\mathrm{th}}$ for air conditioning. The biodiesel consumption would be 25,506 L operating 2,784 hours per year. The PV panels would supply $30.3 \mathrm{MWh}_{\mathrm{e}}$ or $27.3 \%$ of the total electricity produced. It should be noted here that $18.7 \mathrm{kWh}_{\mathrm{e}}$ of excess electricity could be produced, which could neither be stored in the $51 \mathrm{kWh}$ batteries nor be used directly. This is mostly due to peak sunshine hours, where no occupants are in the dwellings (s. Fig. 1). An adequate control mechanism to manage these excess electricity loads should be installed. Additionally, a smarter control system could use this energy for increased efficiency. The roof area needed per dwelling would be $8.25 \mathrm{~m}^{2}$, comfortably below the $48.8 \mathrm{~m}^{2}$ available per dwelling.

Table 1. Component sizes and annual production / throughput of cost-optimal system

\begin{tabular}{|l|l|l|}
\hline Component & Size & Annual use / throughput \\
\hline Generator & $61.0 \mathrm{~kW}_{\mathrm{e}}$ & $80.7 \mathrm{MWh}_{\mathrm{e}} / 111.6 \mathrm{MWh}_{\mathrm{th}}$ \\
\hline $\mathrm{PV}$ & $16.5 \mathrm{~kW} / 132 \mathrm{~m}^{2}$ & $30.3 \mathrm{MWh}_{\mathrm{e}}$ \\
\hline Batteries & $51 \mathrm{kWh}$ & $14.2 \mathrm{MWh}_{\mathrm{e}}$ \\
\hline $\begin{array}{l}\text { System con- } \\
\text { verter }\end{array}$ & $16.9 \mathrm{~kW}_{\mathrm{e}}$ & $40.3 \mathrm{MWh}_{\mathrm{e}}$ (Inv. \& Rect.) \\
\hline ACh & $54 \mathrm{~kW}_{\text {th }}$ & $53.5 \mathrm{MWh}_{\mathrm{th}}$ \\
\hline EChs & $104.3 \mathrm{~kW}$ th $\left(57.1 \mathrm{~kW}_{\mathrm{e}}\right)$ & $86.1 \mathrm{MW}_{\text {th }}$ \\
\hline Electric grid & Unlimited & $118.1 \mathrm{MWh}_{\mathrm{e}}$ \\
\hline
\end{tabular}

The costs for each component are illustrated in Fig. 1. It should be remembered, that the electricity cost values used were before the government subsidies. The system costs over the project lifetime of twenty years amount to 593 kUSD for the entire neighbourhood block. The total capital costs amount to $191 \mathrm{kUSD}$, mostly due to the installation of the batteries and of the cooling system. However, the fuel costs outweigh the capital costs by far with 281 kUSD over the entire system lifetime. 


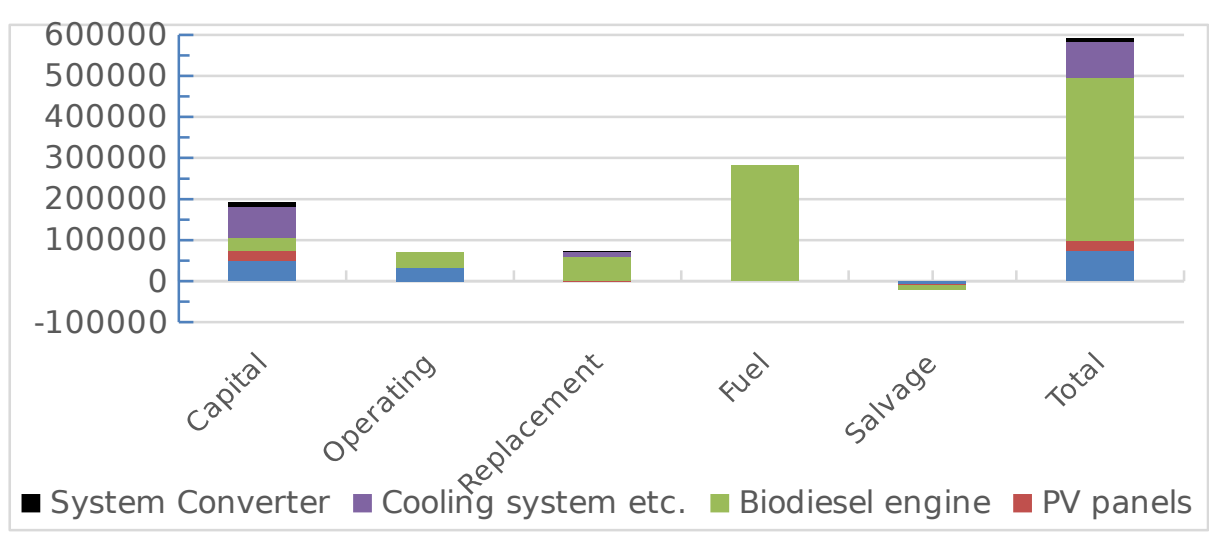

Fig. 1. Cost of each component

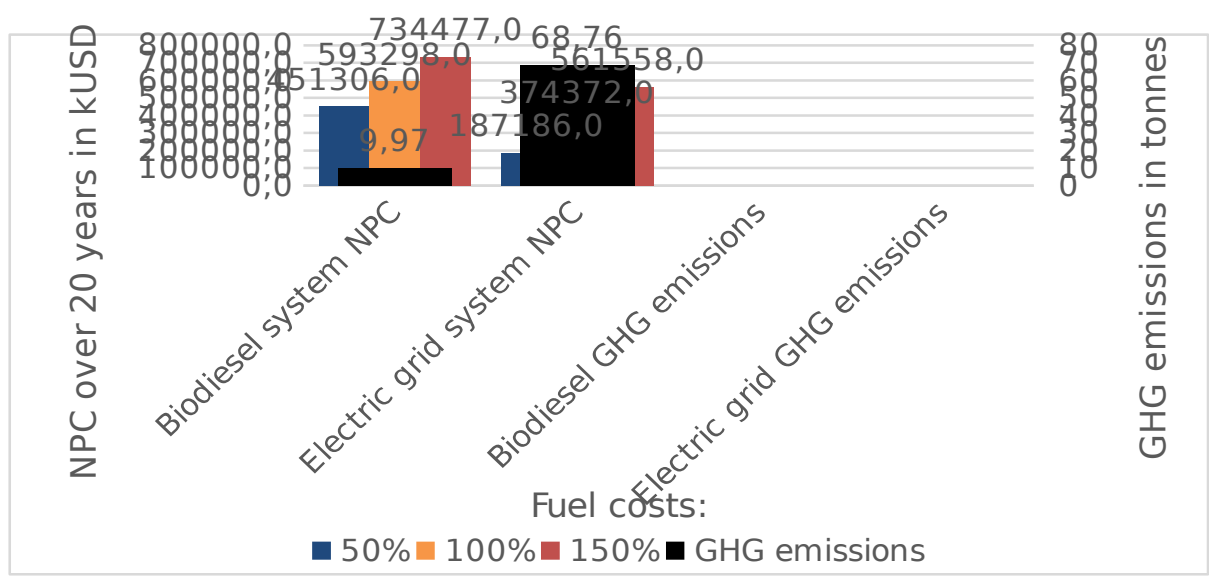

Fig. 1. NPC costs with varying fuel prices and GHG emissions ${ }^{2}$

${ }^{2}$ GHG emissions for electricity: $0.582 \mathrm{~kg} / \mathrm{kWh}$ [19]; GHG emissions for biodiesel: $0.12 \mathrm{~kg} / \mathrm{kWh}$ [20]

Following the high impact of the biodiesel cost, the NPCs with varying biodiesel and electricity prices have been calculated for both systems and are shown in Fig. 1. In comparison, the polygeneration system is 219 kUSD more expensive than the reference system over the project lifetime of 20 years. Even when considering a 50\% cheaper biodiesel price, the reference system would still be less expensive with the current costs of electricity production. However, the reference system is far more affected by rising fuel prices than the polygeneration system, which has a higher level of autonomy due to the PV panels and the batteries. Fig. 1 also illustrates the GHG emissions of each system. The proposed system would produce 58.8 tonnes of GHG emissions less per year or $14 \%$ of what the reference system produces annually.

\section{$5 \quad$ Discussion and Conclusions}

The energetic consumption of a one-family dwelling in Hermosillo, Mexico, was studied and an energy demand model was created for an entire dwelling block using 
the data. During summer, the thermal demand increases significantly due to high electricity demands for the AC system. Based on the model, a more energy-efficient polygeneration system was proposed, which allows the neighbourhood to live completely independent of the electric grid. The system would use an engine fuelled with biodiesel, providing electricity and exhaust heat, which would be used in an absorption chiller to supply cooling energy for air conditioning. The system is supported by PV panels and batteries. The component sizes of the system have been optimized for the lowest NPC.

Although the polygeneration system has a higher energy efficiency, the results show that it is economically inferior to the reference system. Even over a period of 20 years, the high capital investment costs would not have been mitigated. Nonetheless, the system performs economically close to the reference system despite of the low electricity production costs in Mexico. The polygeneration system also shows great ecologic potential, lowering the GHG emissions down to $14 \%$ compared to the reference system.

If designing a system for more dwellings, the relative capital and operation costs could be reduced further. Moreover, the AC system behaviour was not adjusted to the polygeneration system in the simulation leading to excess electricity and heat, which have to be dumped. Additionally, the demand for hot water was not considered, which could imply further savings for the dwelling inhabitants. With an entirely autonomous off-grid system, an extreme case was studied while many grid-connected designs with varying component sizes for renewable energies are possible and could combine economic and ecologic benefits to a certain degree. The effects of such systems on the electric grid should also be considered.

The study indicates that fully autonomous energy systems in urban areas are still a costly alternative to conventional systems. However, further technologic advances coupled with precise political incentives could make such systems a more cost-effective and much more sustainable alternative in the near future.

\section{Acknowledgments}

This research has been conducted in collaboration between UPC (Universitat Politècnica de Catalunya) and KTH Royal Institute of Technology, funded through Erasmus Mundus Joint Doctoral Programme SELECT+, the support of which is gratefully acknowledged. A. I. acknowledges the Spanish project MOET_BIA2016-77675-R. Special thanks are given to Prof. Dr. Helena Coch for encouragement throughout the work.

\section{References}

1. Le Quéré C, Andrew RM, Friedlingstein P, et al (2018) Global carbon budget 2018. Earth Syst Sci Data 10:2141-2194. https://doi.org/10.5194/essd-10-2141-2018

2. Hargreaves T, Hielscher S, Seyfang G, Smith A (2013) Grassroots innovations in community energy: The role of intermediaries in niche development. Glob Environ Chang 23:868-880. https://doi.org/10.1016/J.GLOENVCHA.2013.02.008

3. Wegener M, Malmquist A, Isalgué A, Martin A (2018) Biomass-fired combined cooling, heating and power for small scale applications - A review. Renew Sustain Energy Rev 96:392-410. 
https://doi.org/10.1016/j.rser.2018.07.044

4. Liu H (2011) Biomass fuels for small and micro combined heat and power (CHP) systems: resources, conversion and applications. In: Small and Micro Combined Heat and Power (CHP) Systems. pp 88-122

5. Maraver D, Sin A, Sebastián F, Royo J (2013) Environmental assessment of CCHP (combined cooling heating and power) systems based on biomass combustion in comparison to conventional generation. Energy 57:17-23. https://doi.org/10.1016/j.energy.2013.02.014

6. Caliano M, Bianco N, Graditi G, Mongibello L (2017) Design optimization and sensitivity analysis of a biomass-fired combined cooling, heating and power system with thermal energy storage systems. $\quad$ Energy Convers 149:631-645. https://doi.org/10.1016/J.ENCONMAN.2017.07.048

7. Chua KJ, Yang WM, Er SS, Ho CA (2014) Sustainable energy systems for a remote island community. Appl Energy 113:1752-1763. https://doi.org/10.1016/J.APENERGY.2013.09.030

8. Zhang X, Lovati M, Vigna I, et al (2018) A review of urban energy systems at building cluster level incorporating renewable-energy-source (RES) envelope solutions. Appl Energy 230:10341056. https://doi.org/10.1016/J.APENERGY.2018.09.041

9. DesignBuilder Software Ltd - Home. https://designbuilder.co.uk//. Accessed 1 Feb 2019

10. Homer Energy (2019) HOMER - Hybrid Renewable and Distributed Generation System Design Software. https://www.homerenergy.com/support/docs/3.10/glossary.html. Accessed 19 Feb 2019

11. Reeves G, Gillespie KL, Cowan JD, Frazell C (2002) ASHRAE Guideline 14-2002: Measurement of Energy and Demand Savings

12. Wang Z, Zhao J (2018) Optimization of passive envelop energy efficient measures for office buildings in different climate regions of china based on modified sensitivity analysis. Sustain 10:. https://doi.org/10.3390/su10040907

13. Lau KY, Tan CW, Yatim AHM (2015) Photovoltaic systems for Malaysian islands: Effects of interest rates, diesel prices and load sizes. Energy 83:204-216. https://doi.org/10.1016/J.ENERGY.2015.02.015

14. Riegelhaupt E, Odenthal J, Janeiro L, Koper M (2016) Diagnóstico de la situación actual del biodiésel en México y escenarios para su aprovechamiento

15. Coronado CR, Yoshioka JT, Silveira JL (2011) Electricity, hot water and cold water production from biomass. Energetic and economical analysis of the compact system of cogeneration run with woodgas from a small downdraft gasifier. Renew Energy 36:1861-1868. https://doi.org/10.1016/j.renene.2010.11.021

16. Schopfer S, Tiefenbeck V, Staake T (2018) Economic assessment of photovoltaic battery systems based on household load profiles. Appl Energy 223:229-248. https://doi.org/10.1016/J.APENERGY.2018.03.185

17. Fraunhofer ISE (2019) Aktuelle Fakten zur Photovoltaik in Deutschland. www.pv-fakten.de. Accessed 1 Feb 2019

18. Department of Energy \& Climate Change (2015) URN 15D/022 - Assessment of the Costs, Performance, and Characteristics of Heat UK Networks. London

19. (2017) Factor de Emisión del Sector Eléctrico Nacional. https://www.gob.mx/cms/uploads/attachment/file/304573/Factor_de_Emisi_n_del_Sector_El_ctrico_Nacional_1.pdf. Accessed 5 Feb 2019

20. Clark DH (2013) CO2 emissions from biomass and biofuels. In: What colour is your building? p 10 
